\title{
Two Facets of Organizational Politics, the Constructive and Destructive Role of Organizational Politics on Employee Work Related Attitudes: A Theoretical Study
}

\author{
Noor un Nissa Shahani ${ }^{1,}$, Muhammad Nawaz ${ }^{2}$, Anam Syed ${ }^{3}$ and Nazia Dharejo ${ }^{2}$ \\ ${ }^{1}$ Alhamd Islamic University, Islamabad, Pakistan \\ noor.baloch@alhamd.pk \\ ${ }^{2}$ University of Sindh, Jamshoro, Pakistan \\ mnawaz@usindh.edu.pk; ndharejo@usindh.edu.pk \\ ${ }^{3}$ Sir Syed CASE institute of Technology, Islamabad \\ sanam@case.edu.pk \\ Correspondence: noor.baloch@alhamd.pk
}

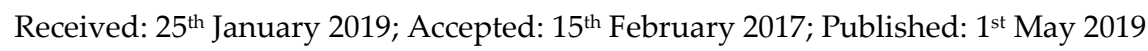

\begin{abstract}
The aim of study this to enhance understanding of employee's attitude towards organizational politics. The positive and negative impact of perception of organizational politics on employee job attitudes is discussed in this paper which caters to one of the most significant issue attracting much of attention by organizational scientists. Numerous productive and counter productive work attitudes are identified by extensive literature review of research papers, articles and different sources at internet. An extensive study of literature has been carried out to discuss two theoretical models of perception of politics. Therein, the article sheds light on the positive outcomes of politics through the first model followed by underlining the negative outcomes of politics at the workplace. The paper also enlightens readers' knowledge and understanding on how organization can work to make the most of this prospect whilst ensuring it does not affect any organizational objectives. The review also forwards lays discussion on both the models for scholars enthusiastic to test and confirm the assertions of both the models for better managerial implication in future.
\end{abstract}

Keywords: Perception of Organizational Politics (POP); Positive; Negative; Job Attitude; Political Behaviour

\section{Introduction}

There are two aspects of organisational politics at workplace one, it is social factor that positively impacts organization and other is self-centred factor serving particularly for self-advantage and selfinterest thus it effects objective of organization (Mintzberg, 1985: 148; Gotsis \& Kortezi, 2010: 498). As 
said by Allen et al, 1979organisational politics therefore considered as dual aspect concept that can be either functional or dysfunctional for the employees and organisations. Likewise, it is argued by Othman in 2008 that Organisational politics is discussed as a positive and negatively by numerous researchers. This paper also gives a detailed insight of both sides of the organisational politics by review of extensive literature throughout the years.

Studies including Gandz \& Murray, 1980; Mayes \& Allen, 1977; Mintzberg, 1983; Pfeffer, 1981, 1992 concluded that "politics is an epidemic phenomenon in organizations and that it deserves more attention and empirical examination". The impact of organizational politics (OP) totally depend upon the causes and consequences whether it works constructively or destructively. In this study with there are two theoretical models are explored one the positive outcomes of politics within organizations and negative outcomes of organizational politics.

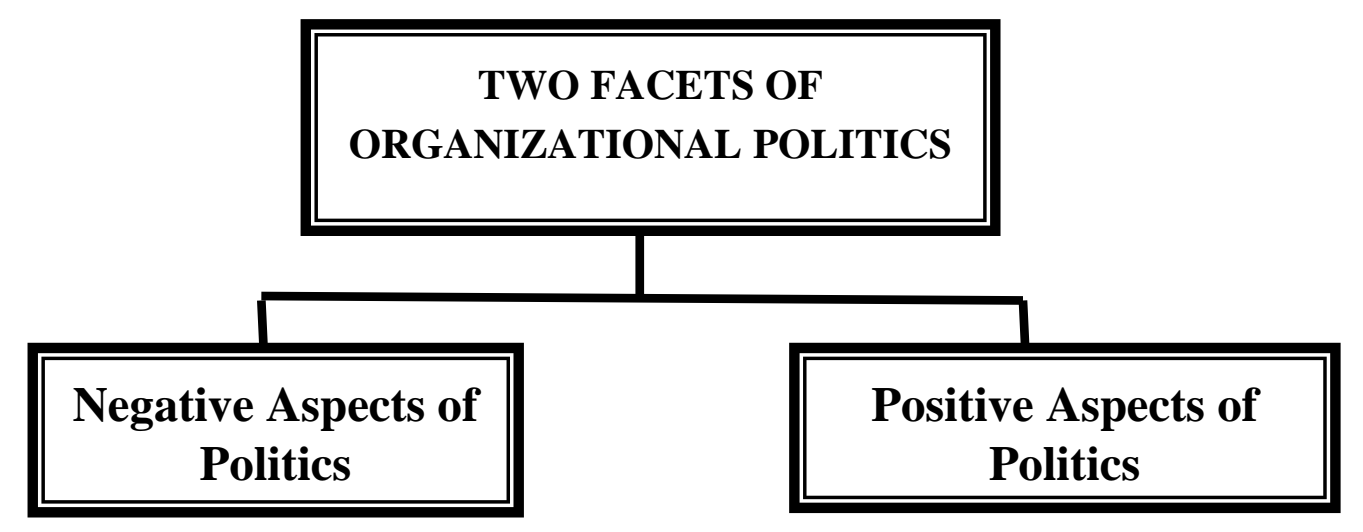

Figure 1. Organizational Politics Factors

\section{Literature Review}

Vigoda in 2000 conducted a study, which concluded that "Perception of organizational politics has negative relationship with job attitudes including job satisfaction and organizational commitment, a positive relationship with intention to leave the organization (exit), and a stronger positive relationship with negligent behaviour (neglect)".

The study by (Ahmed, Khalid, Ahmed \& Shah, 2016; Shahani, 2017) also concluded "that some variable have positive relationship with politics including burnout while few variables having negative relation with politics including job satisfaction".

\section{Introduction to Organizational Politics}

As said by Molm (1997) organization is societal body in which people take part and strive for resources, vested interest, and use different set of techniques to achieve their goal. However (Ferris, Russ, \& Fandt, 1989 define organizational politics is a set of conduct which is specifically designed for achieving personal gains. As it is strategically organized for self-interest, so it only uses for individualism rather than collectivism (Umrani, Mahmood \& Ahmed, 2016). This is the reason this concept generally considered as negative in the perception of every employee at workplace.

Likewise, various authors argued that politics impact negatively at work place including Block in 1988 concluded "If I told you were a very political person, you would take it either as an insult or at best as a mixed blessing". Also, some authors mentioned that majority employees in the organization explain politics as a negative process within organization (Gandz \& Murray, 1980). Additionally, Kacmar (1992) also found that perception of politics is considered as self-centred process to gain self-benefit and self-interest rather for the interest of entire organisation. Also concluded that politics in organization is directly linked with "manipulation", "defamation", "subversiveness", and "illegitimate" ways of use of power to achieve individual's objectives. Ferris et al. in 1989 recommended that "the concept of perception of organizational politics (Perception of Organizational Politics Scale-POPS) as a good measure of OP". Kacmar and Ferris (1991) and Ferris 
and Kacmar (1992) discussed that having perceptions of extreme politics within employee's results injustice and inequity.

\section{Outcomes of Politics Perception}

In first model we discuss the positive outcomes of perception of politics at workplace. "Positive organisational politics may provide the basis for competitive advantage, especially when people are appropriately politically skilled". Moreover, it was also discussed by different researcher including Drory \& Vigoda-Gadot, 2010; Gotsis \& Kortezi, 2010 that "politically skilled management successfully manages those organisational environments that are under stress - a political skill that includes an aptitude to employ actions that support feelings of trust, confidence and sincerity". Likewise, it is argued by Drory \& Vigoda-Gadot (2010) that there is effective environment of positive politics then organization will not agonise from "injustice", "unfairness" and "inequity".

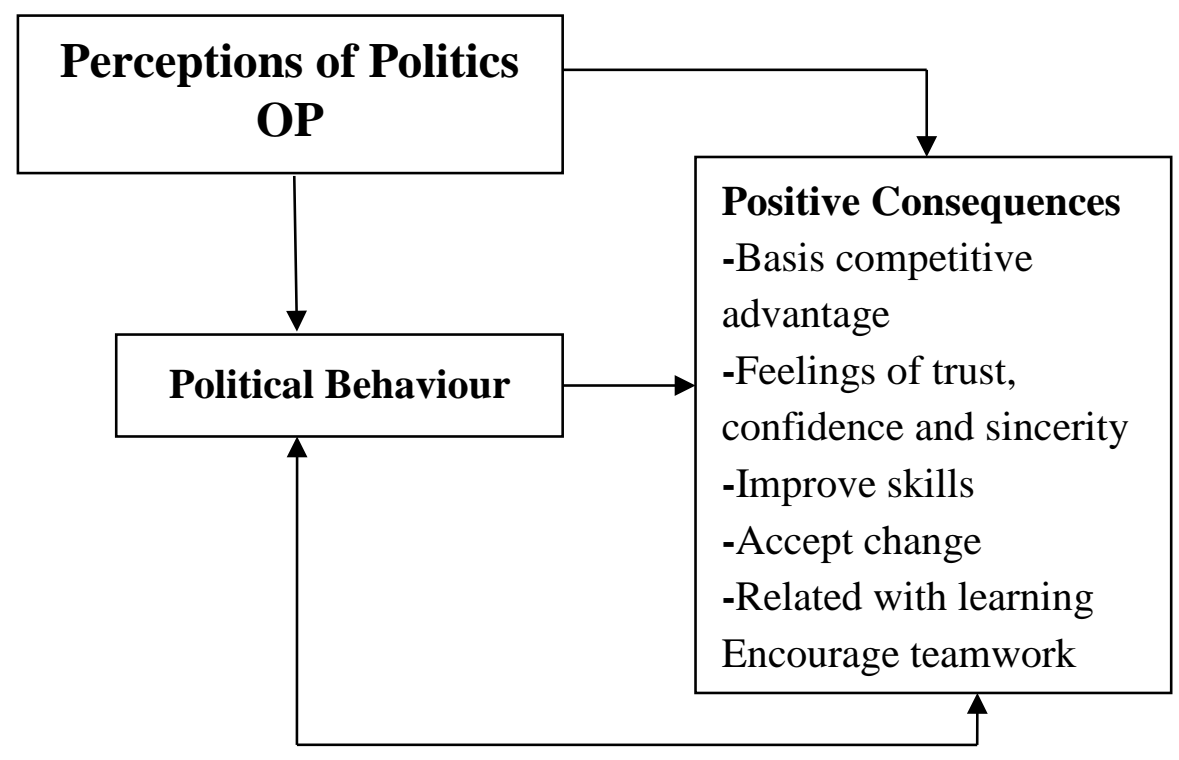

Figure 2. Perceptions of Politics

Some authors including Ladebo, 2006: Vredenburgh \& Shea-VanFossen, 2010 argued that by help of exercising politics individual improve skills which contribute in organizational success and it also enable organization to accept change in environment. Also, Kurchner-Hawkins and Miller (2006) argued that no doubt political behaviour is positive when it uses to accomplished organizational objectives, and encourage teamwork and ethical work behaviour. Moreover, it is found by Gotsis \& Kortezi, 2010 that positive or constructive political behaviour is highly related to organisational justice.

Furthermore, it is found by Butcher and Clarke (2006) that managers perceived political environment at workplace then they maintain their political behaviours to promote equality and justice at workplace. It is also concluded by Kurchner, Hawkins and Miller (2006) that organisational politics is a key leadership factor which positively influence environment and improve efficiency of an organisation. Consequently, it is found by Gotsis \& Kortezi, 2010 that if political behaviour is viewed as natural and constructive factor at workplace, then it helps to developed political strategies with affiliation and guidance.

Moreover, according to Kurchner, Hawkins and Miller (2006) people perceived politics as positive whose goals are aligned with the organisation's goals and objectives. It is also concluded by Coopey \& Burgoyne (2000) that a "liberal form of politics" is positively related with learning.A study by Vigoda-Gadot \& Kapun in 2005 provided a set of positive outcomes of politics named as "career advancement, recognition and status, enhanced power and position, attainment of personal and organisational goals, successful accomplishment of a job or policy implementation, and feelings of achievement, ego, control and success". 
It is also argued by Drory and Vigoda-Gadot, 2010 that if someone want to make his/her distinct space within organizational he/she must have efficient political behaviour to be acknowledged by his or her peers. Mintzberg in 1985 introduced "several positive aspects of organisational politics in relation to his identification of games". He states that organisational politics is can be used for to get due rights for example it works for whistle blowing and Young Turks games, it could also help to rectifying negligent or unproductive behaviours and even can encourage the beneficial changes. Accordingly, it is concluded by Luthans et al in 1985 "there is a relationship between successful managers and the frequent use of organisational politics". In fact, Kurchner-Hawkins and Miller (2006) state that leadership is "a political art rather than a strategic science". As stated by VigodaGadot and Drory (2006) and Mintzberg (1985) the "Organisational politics may also encourage a variety of voices to be heard that may be beneficial to the organisation". Furthermore, it is also discussed by Parker et al. (1995) that "OP was not related to job satisfaction, loyalty, senior management effectiveness, and endorsements of positive organization values".

Even though organisational politics is concluded positive by various studies (Drory \& VigodaGadot, 2010; Othman, 2008; Poon, 2003), but majority of individuals perceive politics as negative at workplace. Therefore, there are many definitions of organizational politics OP by which it considers as negative workplace activities that can result destructive work-related outcomes. A well-known statement given by Block in 1988 states that "If I told you, you were a very political person you would either take it as an insult or at best as a mixed blessing". Hence it is concluded by Gotsis \& Kortezi, 2010; Harris et al, 2009; Ladebo, 2006; Vigoda Gadot \& Kapun, 2005 that generally political work environment is viewed as negative by employees and they may sense the "unfairness", "deprivation" and "inequity" at workplace. Subsequently, it is found by Beugré \& Liverpool and Harris et al, 2009 that "employees who perceive politics at workplace tend to withhold useful information and feel threatened by the uncertainty, ambiguity and the self-interest actions that occur with individuals". Ahmed, Mozammel and Ahmed (2018) and Vredenburgh and SheaVanFossen (2010) argue that "genetic tendencies such as forcefulness, power and control need, manipulation, rank rivalry, and egotism can all materialize in response to common organisational circumstances of uncertainty, resource shortage, and disagreement". In matter of fact, several researchers found including Drory, 1993; Ferris et al, 1989; Gotsis \& Kortezi, 2010; Vigoda-Gadot \& Kapun, 2005 that "organisational politics have a negative effect on the job performance and organisational commitment (Umrani, Kura \& Ahmed, 2018), especially to the lower status employees". Other researcher including Ladebo, 2006; Vigoda-Gadot and Kapun (2005) proposed that organisational politics related to stress and conflict at the workplace. Ferris et al. (1993) concluded that politics related to job anxiety.

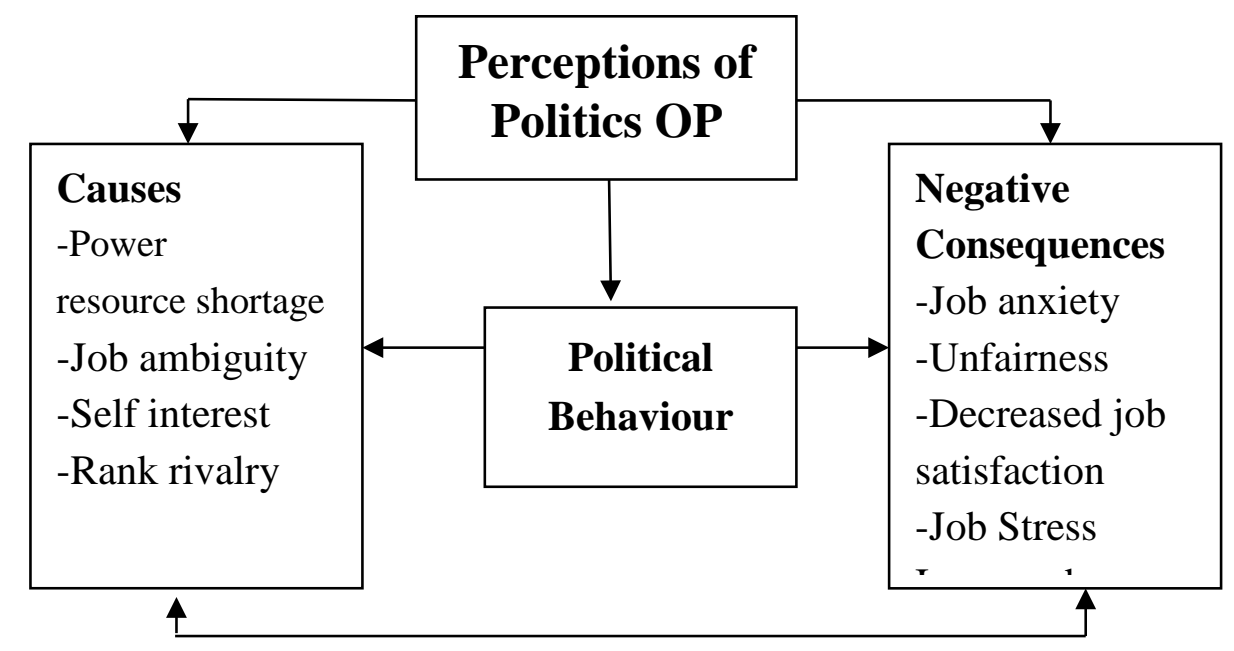

Figure 3. Negative Consequences of Perceptions of Politics

Li and Cropanzano (2009) found that politics can impact negatively even for those who are not directly in politics. As said by Curtis (2003) that the "'Machiavellianism' and 'locus of control' as 
examples of particular characteristics of highly political individuals". Chircop (2008) referred that organisational politics or 'workplace toxins.

Various studies including Ferris et al. (1996) have concluded that when employee perceive injustice within organization, they also perceive high level organizational politics at workplace, which affect organizational outcomes. As these studies based on Lewin (1936) argue that "people respond to their perceptions of reality, not to reality itself". So, employees always react as they think not on actual situation or circumstances. Moreover, numerous studies including Ferris, Kacmar, and their colleagues in numerous studies (e.g.Ferris et al., in 1996; Ferris et al., 1994); Ferris \& Kacmar, 1992) concluded that perceptions of justice at workplace reflects political scenario of the organizations which also directed indirectly effects work related outcomes of the employees. Furthermore Parker et al. (1995) also discussed that employee who perceived politics at workplace he/she consider organization as less encourage the innovation at workplace. Ferris (1989) concluded "three potential responses: increased job anxiety, decreased job satisfaction, and withdrawal from the organization". Many other studies also relate politics with variety of counter productive work attitudes including Later studies confirmed some of these relationships. Likewise, Drory (1993) found that job satisfaction and organizational commitment are negatively co related with perceptions of politics and also discussed that perceptions of politics cause frustration and shows high level of politics at workplace which creates negative image of organization's environment. Some studies like Drory, (1993) and Ferris et al. (1996) concluded a negative relationship between perceptions of politics OP and job attitudes or stress-related responses. Similarly, other studies including Cropanzano, Howes, Grandey and Toth (1997) also suggested that politics enhances withdrawal behaviours and turnover intentions.

Cropanzano et al. (1997) recommends that employees who view the organization as political in nature maybe it causes psychological and physically withdrawals. Also, employees work there with absent minds this is theoretically discussed "empirical studies provide only marginal support for this idea" (e.g., Bozeman et al., 1996).

Hulin, 1991 discovered some symptoms of psychological withdrawal due to internal politics including Symptoms of, like continues "daydreaming" or "chatting" to co-workers about non-workrelated matters (e.g., internal politics) that is much like "negligent behaviour".

Similarly, Vardi and Wiener (1996) found "that negligent behaviour may also reflect misbehaviours or activities that damage the organization, not always because of overtly vicious intentions but sometimes through irresponsibility or sloppiness stemming from low attachment to or lack of identification with it". Ferris et al. (1998) applied the ideas of Hirschman (1970) found that OP may result in negative consequences, including low level of job satisfaction, high level of neglect behaviour, or intention to quit.

Previous studies such as Mossholder and colleagues (1988) have found that intention to turnover and job performance are negatively co related. Other studies like Ferris et al. (1996) concluded job anxiety, job tension, burnout is results of political behaviour at workplace.

\section{Conclusion}

It is concluded by Drory \& Vigoda-Gadot (2006); Gotsis and Kortezi (2010) that negative organisational politics are disapproved of because it doesn't not fulfil ethical paradigm and caused by conflicts at workplace other hand positive organisational politics promote teamwork and caused common goals.

Drory and Vigoda-Gadot (2006) found "that the 'unitary' notion of organisations affirms that the members of an organisation work towards common goals and objectives in a pleasant setting wherein political action can be seen as anomalous". Therefore, as stated said by Curtis (2003) everyone can't ignore politics at workplace specially some peoples with distinct personality types are mostly like to evolve in organisational politics, like Machiavellian personalities which concerned for 'grand' need for power. Employees should be politically skilled to communicate their ideas among employees at workplace. Managers must understand that organisations need active actors who are willing to engage in political behaviour that pushes ideas forward". 


\section{References}

Ahmed, U., Khalid, N., Ammar, A., \& Shah, M. H. (2017). Assessing moderation of employee engagement on the relationship between work discretion, job clarity and business performance in the baking sector of Pakistan. Asian Economic and Financial Review, 7(12), 1197-1210.

Ahmed, U., Mozammel, S., \& Ahmed, H. (2018). Performance on the road: examining the critical role of training effectiveness amongst the blue-collar employees in Bahrain. Asian Journal of Empirical Research, 8(9), 342-351.

Allen, R. W., Madison, D. L., Porter, L. W., Renwick, P. A., \& Mayes, B. T. (1979). Organizational politics: Tactics and characteristics of its actors. California Management Review, 22(1), 77-83.

Block, P. (2016). The empowered manager: Positive political skills at work. John Wiley \& Sons.

Butcher, D. \& Clarke, M. (2006) The Symbiosis of Organizational Politics and Organizational Democracy, in E. VigodaGadot and A. Drory (eds.), Handbook of Organizational Politics (Edward Elgar, Cheltenham, UK), pp. 286300 .

Chircop, M. P. (2008). The Games that People Play, The Executive, Issue 15: pp. 5-9. Coopey, J. \& Burgoyne, J. (2000) Politics and Organizational Learning, Journal of Management Studies, 37(6), 869-885.

Cropanzano, R., Howes, J. C., Grandey, A. A., \& Toth, P. (1997). The relationship of organizational politics and support to work behaviors, attitudes, and stress. Journal of Organizational Behavior: The International Journal of Industrial, Occupational and Organizational Psychology and Behavior, 18(2), 159-180.

Curtis, S. (2003). Lies, damned lies and organisational politics. Industrial and Commercial Training, 35(7), $293-297$.

Drory, A. (1993). Perceived political climate and job attitudes. Organization Studies, 14(1), 59-71.

Drory, A., \& Vigoda-Gadot, E. (2010). Organizational politics and human resource management: A typology and the Israeli experience. Human Resource Management Review, 20(3), 194-202.

Ferris, G. R. et al (1989) Politics in organizations, in R.A. Giacalone \& P. Rosenfield (eds), Impression management in the organization, Hillsdale, NJ: Lawrence Erlbaum, pp. 143-70.

Ferris, G. R., Russ, G. S., \& Fandt, P. M. (1989). Politics in organizations. In R. A. Giacalone \& P. Rosenfeld (Eds.), Impression management in the organization (pp. 143-170).

Folger, R., Konovsky, M. A., \& Cropanzano, R. (1992). A due process metaphor for performance appraisal. In L. L. Cummings \& B. M. Staw (Eds.), Research in organizational behavior (Vol. 14, pp. 129-177). Greenwich, CT: JAI Press.

Gandz, J., \& Murray, V. V. (1980). The experience of workplace politics. Academy of Management Journal, 23(2), 237-251.

Gotsis, G. N., \& Kortezi, Z. (2010). Ethical considerations in organizational politics: Expanding the perspective. Journal of Business Ethics, 93(4), 497-517.

H. (1985). The organization as political arena. Journal of Management Studies, 22(2), 133-154.

Harris, K. J., et al (2009) Relationships Between Politics, Supervisor Communication, and Job Outcomes, Journal of Applied Social Psychology, 39(11), 2669-2688.

Hirschman, A. O. (1970). Exit, voice and loyalty. Cambridge, MA: Harvard Univ. Press.

Hulin, C. L. (1991). Adaptation, persistence, and commitment in organizations. In M. D. Dunnette \& L. M. Hough (Eds.), Handbook of industrial and organizational psychology (2nd ed., Vol. 2, pp. 445-506), Palo Alto, CA: Consulting Psychologists Press.

Kacmar, K. M., \& Carlson, D. S. (1994). Further validation of the perceptions of politics scale (POPS): A multiple sample investigation. Paper presented at the Academy of Management Meeting, Dallas, TX.

Kacmar, K. M., \& Ferris, G. R. (1991). Perceptions of organizational politics scale (POPS): Development and construct validation. Educational and Psychological Measurement, 51(1), 193-205. 
Kurchner-Hawkins, R., \& Miller, R. (2006). Organizational politics: Building positive political strategies in turbulent times. Handbook of Organizational Politics, 1, 328-351.

Ladebo, O. J. (2006) Perceptions of Organisational Politics: Examination of a Situational Antecedent and Consequences among Nigeria's Extension Personnel, Applied Psychology: An International Review, 55(2), $255-281$.

Lawrence, T. B., et al (2005) The Politics of Organizational Learning: Integrating Power into the 4I Framework, Academy of Management Review, 30(1), 180-191.

Lewin, K. (1936). Principles of topological psychology. New York: McGraw-Hill.

Li, A., \& Cropanzano, R. (2009). Fairness at the group level: Justice climate and intraunit justice climate. Journal of Management, 35(3), 564-599.

Luthans, F., Rosenkrantz, S. A., \& Hennessey, H. W. (1985). What do successful managers really do? An observation study of managerial activities. The Journal of Applied Behavioral Science, 21(3), 255-270.

Mayes, B. T., \& Allen, R. W. (1977). Toward a definition of organizational politics. Academy of Management Review, 2(4), 672-678.

Mintzberg, H. (1985). The organization as political arena. Journal of Management Studies, 22(2), 133-154.

Mintzberg, H. (1983). The case for corporate social responsibility. Journal of Business Strategy, 4(2), 3-15.

Molm, L. D. (1997). Coercive power in social exchange. Cambridge: Cambridge Univ. Press.

Mossholder, K. W., Bedeian, A. G., Norris, D. R., Giles, W. F., \& Feild, H. S. (1988). Job performance and turnover decisions: Two field studies, Journal of Management, 14(3), 403-414.

Noor.S, Muhammad. N, Ashique, J, Jamshed. H (2017) perception of politics (pop) and mediating role of justice on job satisfaction and work-related burnout among administrative and academic staff in universities of sindh, European Journal of Business and Social Sciences, 6(2), 207-218

Othman, R. (2008) Organisational Politics: The Role of Justice, Trust and Job Ambiguity, Singapore Management Review, 30 (1), 43-53.

Parker, C. P., Dipboye, R. L., \& Jackson, S. L. (1995). Perceptions of organizational politics: An investigation of antecedents and consequences. Journal of Management, 21(5), 891-912.

Pfeffer, J., \& Pfeffer, J. (1981). Power in organizations (Vol. 33). Marshfield, MA: Pitman.

Poon, J. (2003) Situational Antecedents and Outcomes of Organisational Politics and Perceptions, Journal of Managerial Psychology, 18(2), 138-155.

Seo, M. G. (2003). Overcoming emotional barriers, political obstacles, and control imperatives in the actionscience approach to individual and organizational learning. Academy of Management Learning $\mathcal{E}$ Education, 2(1), 7-21.

Umrani, W. A., Mahmood, R., \& Ahmed, U. (2016). Unveiling the direct effect of corporate entrepreneurship's dimensions on the business performance: a case of big five banks in Pakistan. Studies in Business and Economics, 11(1), 181-195.

Umrani, W. A., Kura, K. M., \& Ahmed, U. (2018). Corporate entrepreneurship and business performance: The moderating role of organizational culture in selected banks in Pakistan. PSU Research Review, 2(1), 59-80.

Vardi, Y., \& Wiener, Y. (1996). Misbehavior in organizations: A motivational framework. Organization Science, 7(2), 151-165.

Vigoda, E. (2000). Internal politics in public administration systems: An empirical examination of its relationship with job congruence, organizational citizenship behavior, and in-role performance. Public Personnel Management, 29(2), 185-210. 
Vigoda-Gadot, E. \& Kapun, D. (2005) Perceptions of politics and perceived performance in public and private organisations: a test of one model across two sectors, Policy $\mathcal{E}$ Politics, 33(2), 251-276.

Vigoda-Gadot, E. (2007) Leadership style, organizational politics, and employees' performance: An empirical examination of two competing models, Personnel Review, 36(5), 661-683.

Vigoda-Gadot, E., \& Drory, A. (Eds.). (2006). Handbook of organizational politics. Edward Elgar Publishing.

Vince, R. (2001) Power and emotion in organizational learning, Human Relations, 54(10), 1325-1351.

Vredenburgh, D. \& Shea Van-Fossen, R. (2010) Human Nature, Organizational Politics and Human Resource Development, Human Resource Development Review, 9(1), pp. 26-47. Zaleznik, A. (1971) Power and Politics in Organizational Life, McKinsey Quarterly, 7(4), 52-69.

Zhou, J., \& Ferris, G. R. (1995). The Dimensions and Consequences of Organizational Politics Perceptions: A Confirmatory Analysis, Journal of Applied Social Psychology, 25(19), 1747-1764.

(C) 2019 by the author(s). Published by Annals of Contemporary Developments in Management \& HR (ACDMHR), under the terms and conditions of the Creative Commons Attribution (CC BY) license which can be accessed at http://creativecommons.org/licenses/by/4.0/. 